\title{
Theropod pedal unguals from the Late Cretaceous (Cenomanian) of Morocco, Africa
}

\author{
Fernando E. NOVAS ${ }^{1,2}$, Fabio DALLA VECCHIA ${ }^{3}$ \& Diego F. PAIS
}

\begin{abstract}
${ }^{1}$ CONICET - Museo Argentino de Ciencias Naturales "Bernardino Rivadavia”, Av. Angel Gallardo 470 Buenos Aires (1405), Argentina. ${ }^{2}$ E-mail: fernovas@yahoo.com.ar. ${ }^{3}$ Museo Paleontologico Cittadino Via Valentinis 134 I-34074 Monfalcone, Gorizia, Italia.
\end{abstract}

\begin{abstract}
Two different theropod pedal unguals from the Upper Cretaceous (Cenomanian) of Tafilalt, Morocco are described. One of them belongs to a slender kind of abelisauroid theropod. Comparison with other members of this group reveals that abelisauroid unguals show high morphological diversity in congruence with what is known on other parts of the skeleton. Another large-sized ungual resembles that described as "Spinosaurus B" by Stromer (1934), and is here referred with caution to Theropoda, although ignoring to which theropod lineage it belongs. Comparisons between northern (e.g., Sahara, Africa and Brazil) and southern (e.g., Patagonia) Gondwanan Cretaceous dinosaur faunas reveal some differences leading to the conclusion that Gondwanan faunas were not uniform across this supercontinent.
\end{abstract}

Key words: Unguals, Theropods, Cretaceous, Africa.

Current knowledge of theropod dinosaurs from the Upper Cretaceous of Africa is deceptively fragmentary and taxonomically confuse. Specimens described by the German paleontologist Ernest Stromer from Cenomanian beds of Egypt, were destroyed during World War II. Thus the only source of information available from outstanding discoveries such as Spinosaurus, Carcharodontosaurus, and Bahariasaurus relays solely on Stromer's monographs (e.g., Stromer, 1915, 1925, 1931, 1934) and some works by French paleontologists (e.g., Deperet \& Savornin, 1927). Later papers devoted to Cretaceous theropods from Africa were published by Lavocat (1954) and Lapparent (1960), but the described material consists of fragmentary bones with poor phylogenetic information. More recently, Rauhut \& Werner (1995), Rauhut (1999), Russell (1996), and Taquet \& Russell (1998) reported isolated remains of theropods of different affiliations (e.g., Deinonychosauria, Spinosauridae, Abelisauridae), which reveal a wide morphological disparity of African theropods.

By far, the most significant theropod findings from Late Cretaceous beds are those reported by Sereno and colleagues from Morocco and Niger, who described more complete cranial and postcranial remains of the Cenomanian carcharodontosaurid Carcharodontosaurus saharicus (Sereno et al., 1996) and the abelisauroids Rugops primus and Deltadromeus agilis (Sereno et al.,
2004), and several Aptian specimens eventually corresponding to a new member of Spinosauridae, Suchomimus tenerensis (Sereno et. al. 1998; however, see Sues et al., 2002, for a different view on the systematic of this theropod).

Among the variety of dinosaur remains found in Cenomanian beds of Northern Africa, theropod ungual phalanges have been frequently recovered (e.g., Stromer, 1934; Rauhut, 1995; Russell, 1996). Similarly to isolated teeth, pedal ungual phalanges may constitute a useful tool for the recognition of different dinosaur taxa in poorly preserved faunal assemblages. For example, abelisauroid unguals are quite distinctive and their isolate finding may prove the presence of this dinosaur clade in Cretaceous theropod assemblages (e.g., Novas \& Bandyopadhyay, 2001). Although unguals offer valuable anatomical information, few comprehensive comparative studies exist on these elements. Unfortunately, available knowledge on the morphological variations among different reptile clades with large-size members (e.g., crocodiles, ornitischian, and theropod dinosaurs) collected from Aptian to Turonian beds, complicate the taxonomic assignment of such isolated pedal elements.

In the present paper we describe the anatomy of some theropod pedal unguals collected in the Upper Cretaceous beds of Southern Morocco, offering anatomical basis for the taxonomic referral of the studied specimens. We also want to call 
the attention about some topical aspects of African theropod taxonomy, mainly concerning with the specimen originally named "Spinosaurus B" (Stromer, 1934), as well as to speculate about theropod paleobiogeography of Gondwana.

\section{Geographical and geological provenance of studied specimens}

The theropod unguals here described were purchased from fossil dealers of Erfoud (Southern Morocco) (S. Piccini, pers. comm.) and belong to the private collection of Dr. Stefano Piccini, Torreano di Cividale del Friuli, Udine province, Italy. These specimens will be hopefully deposited in a paleontological museum that the Geofin company has planned to create in the future near Cividale del Friuli. Nevertheless, casts of the studied specimens are deposited in the Museo Paleontologico Cittadino of Monfalcone, Italy.

Considerable amount of fossils from Tafilalt was collected by local inhabitants and fossil dealers, currently forming part of private collections. Some of these specimens, however, became available for scientific study: Russell (1996) described several dinosaur specimens which are deposited in The Natural History Museum, London, and the Canadian Museum of Nature, Ottawa. Also, Kellner \& Mader (1996, 1997), Mader \& Kellner (1999), and Wellnhofer \& Buffetaut (1999) described pterosaur and dinosaur remains from the same localities housed in paleontological institutions of Europe and North America. Although specimens are biased by inadequacies regarding both the exact geographic and stratigraphic provenances, they are still useful for anatomical analysis.

Specimens here described probably come from the Tafilalt and Kem Kem regions at the northern margin of the Sahara desert. Whereas the Kem Kem region is far south and difficult to reach, Erfoud occurs in the Tafilalt. Many outcrops yielding scattered dinosaur remains can be reached easily from this town and some are quarried from sand by local people (F.M. Dalla Vecchia, pers. obs.). Thus it is much more probable that the dinosaur remains sold in Erfoud come from the close and easy to reach Tafilalt outcrops rather than from the southern Kem Kem ones. Also the fossils described by Russell (1996) were collected and purchased by inhabitants of the Tafilalt. Other fossils in the Piccini's collection and from the same source are mainly teeth referred to Carcharodontosaurus, Spinosaurus, crocodylomorphs, sauropods, pterosaurs, fishes (e.g., Lepidotes, Onchopristis, Hybodus), as well as some bones belonging to crocodylomorphs, and chelonians. Such fossil association is in agreement with that recovered from the dinosaur-bearing rocks of both Tafilalt and Kem Kem regions

Russell (1996) reported the Cretaceous stratigraphy of the Tafilalt escarpment East and South of Erfoud described by Joly (1962). A lower unit named "Grès rouges infracénomaniens", the one which yields fossil remains of dinosaurs, crocodiles and fishes, occurs above Paleozoic (Carboniferous) rocks. It is composed mainly of sandstone deposited in a continental to deltaic environment and in some places is more than 200 $m$ thick. It is overlain by lagoonal or coastal plain beds (i.e., the "Marnes versicolores à gypse"; Joly, 1962) which could reach a thickness of 100-200 $\mathrm{m}$. The sequence is topped by the frankly marine "Calcaire cénomano-turonien", a limestone unit that contains ammonites, as Neolobites vibrayanus, and represents the great Late Cenomanian marine transgression. A similar sequence is found also in the Kem Kem (Sereno et al.,1996). Here the sequence comprised between the Paleozoic and the Late Cenomanian limestone is informally named "Kem Kem beds", and is divided in a lower sandy unit, and an upper unit where mudstone is common, both deposited in deltaic environments and preserving dinosaur remains (Sereno et al.,1996).

According to their stratigraphic position the "Grès rouges infracénomaniens" cannot be younger than Late Cenomanian. They are usually considered to be Albian, Cenomanian or Albian-Cenomanian in age (e.g., Taquet, 1976; Jacobs et al., 1996; Sereno et al., 1996; Russell, 1996). Sereno et al. (1996) dated the fossiliferous levels of Kem Kem as Cenomanian based on the elasmobranch association. The ungual phalanges here described come from the "Grès rouges infracénomaniens", and are accordingly interpreted as Cenomanian.

Abbreviations. BMNH R, Natural History Museum, London, England; MPCA, Museo Provincial "Carlos Ameghino", Cipolletti, Río Negro, Argentina; MPCM, Museo Paleontologico Cittadino di Monfalcone, Gorizia, Italy; MPEFPV, Museo Paleontológico "Egidio Feruglio", Trelew, Chubut, Argentina.

\section{DESCRIPTION OF SPECIMENS}

Abelisauroid pedal ungual (MPCM 13573; Fig. 1). This ungual, presumably belonging to digit IV of left foot, is long and slender, and measures nearly $7 \mathrm{~cm}$ along its dorsal margin. It is arched (presumably medially), with the lateral surface strongly convex and the medial surface 
almost flat. As a result of this asymmetry, the medial surface of the ungual is also exposed dorsally. Both lateral and medial surfaces have wide furrows describing a distinct, proximally bifurcated pattern. On the lateral surface, the proximally bifurcated furrow bounds a triangular and flat zone. On the medial surface there is a unique deep furrow extending almost to the distal apex of the bone. The proximal articular contour is triangular. The dorsal margin is sharp and projects proximally forming a well-developed proximodorsal lip. The ventral surface of the ungual is almost flat, but has a narrow and deep central groove. A proximoventral flexor tubercle is represented by a slight circular eminence.

Unguals like this were not reported before from Cretaceous beds of Africa. The pattern fits well with that of abelisauroid theropods, as documented in Velocisaurus unicus (Bonaparte, 1991), Masiakasaurus knopfleri (Carrano et al., 2002), Aucasaurus garridoi (Coria et al., 2002), an indeterminate abelisaurid from Patagonia (MPCA 56 ; Novas \& Bandyopadhyay, 2001), and several isolated unguals from the Lameta Formation of central India (Huene \& Matley, 1933; Novas \& Bandyopadhyay, 2001; Novas et al., 2004a). Features shared by these different abelisauroids include: proximally "V"-shaped furrows, proximodorsal lip robust, and ventral surface furrowed and almost devoid of flexor tuberosity. Therefore, this African ungual is confidently referred to a gracile, albeit large, abelisauroid.

The pedal ungual here described differs from that of the Patagonian abelisaurid MPCA 56 in that the latter lacks a flexor tuber (Novas \& Bandyopadhyay, 2001), and that in MPCM 13573 the proximally bifurcated furrow bounds a triangular and flat zone, different from the conspicuous bump described for Patagonian and Indian abelisaurids (Novas \& Bandyopadhyay, 2001). Although differences in ungual morphology may in part depend on the position in the foot, the distinctions noted above are congruent with the high taxonomic diversity of abelisauroid theropods. In particular, slender and robust kinds of hind limbs were identified among abelisauroids (e.g., Novas et al., 2004a).

The abelisauroid ungual here described adds to the evidence presented by Russell (1996), and more recently by Sereno et al. (2004) and Mahler (2005), suggesting that this ceratosaurian clade was highly diversified in the Cretaceous of Africa.

Theropoda indet. (MPCM 13574; Fig. 2). This isolated ungual probably belongs to pedal digit III, due to its axial symmetry. It is $12 \mathrm{~cm}$ long, and its transverse section is subtriangular.
It is slightly curved along its dorsal margin, and its ventral surface is flat, thus the ungual results almost straight in lateral aspect. Both lateral and internal surfaces are slightly convex and have a single furrow extending for most of the ungual length. The furrows are located close to the ventral margin of the bone, matching the ungual curvature. The ventral surface is flat, especially on the distal two thirds of the bone. As a result, sharply defined margins separate the ventral side from the medial and lateral surfaces. A semicircular depression exists on the proximal end of the ventral surface. Notably, this depression bears on its center a strong longitudinal ridge, that is flanked by another two, less prominent, oblique ridges. The proximal articular surface is triangular, but its base is slightly convex. The proximodorsal lip is transversely robust.

The same gracile aspect and degree of curvature is also seen in an ungual phalanx that was catalogued as "Spinosaurus B" by Stromer (1934; specimen Nr. 1922 X 45) (Fig. 3C,D), and another one identified as "Carcharodontosaurus saharicus" by Lapparent (1960, pl.VI, 10-12). Slight differences in the degree of curvature, position of the collateral grooves, and development of the proximodorsal lip seen among specimen MPCM 13574 and the unguals described by Stromer (1934) and Lapparent (1960) may reflect their respective correspondence to different digits of the foot rather than different species of a large animal.

Elucidation of the taxonomic allocation of the studied ungual phalanx is obscured for the nature of specimen Nr 1922 x 45 of "Spinosaurus B": this specimen is made up by remains corresponding to more than one individual (Stromer, 1931), and includes a set of cervical, dorsal and caudal vertebrae of a large and bulky animal, and some isolated hind limb bones (e.g., distal femur, tibia, and pedal ungual phalanx) corresponding, instead, to a large but gracile theropod. In reference with the set of vertebrae, the cervicals and caudals have been referred by Russell (1996) to a new theropod taxon, Sigilmassasaurus brevicolis. However, taxonomic validity of Sigilmassasaurus brevicolis was dismissed by Sereno et al. (1996), who considered this taxon as junior synomym of Carcharodontosaurus saharicus, by referring to this later species the vertebral elements and pedal ungual of "Spinosaurus B" described by Stromer in 1931. Recent discovery of the basal carcharodontosaurid Tyrannotitan chubutensis (Novas et $a l ., 2005)$, reveals that such peculiar vertebrae and phalanges do not belong to Carcharodontosauridae. In particular, a pedal ungual be- 

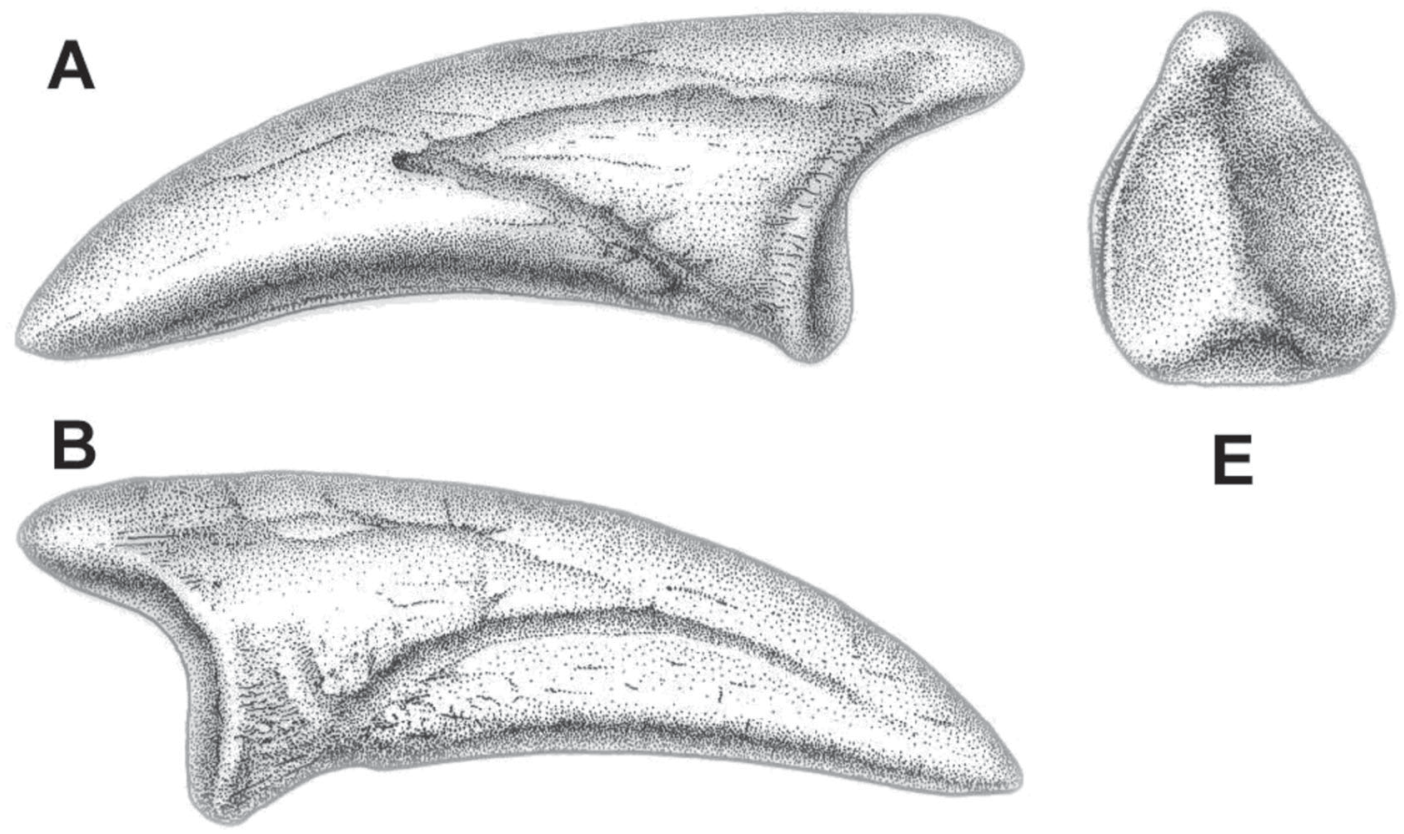

$\mathbf{E}$
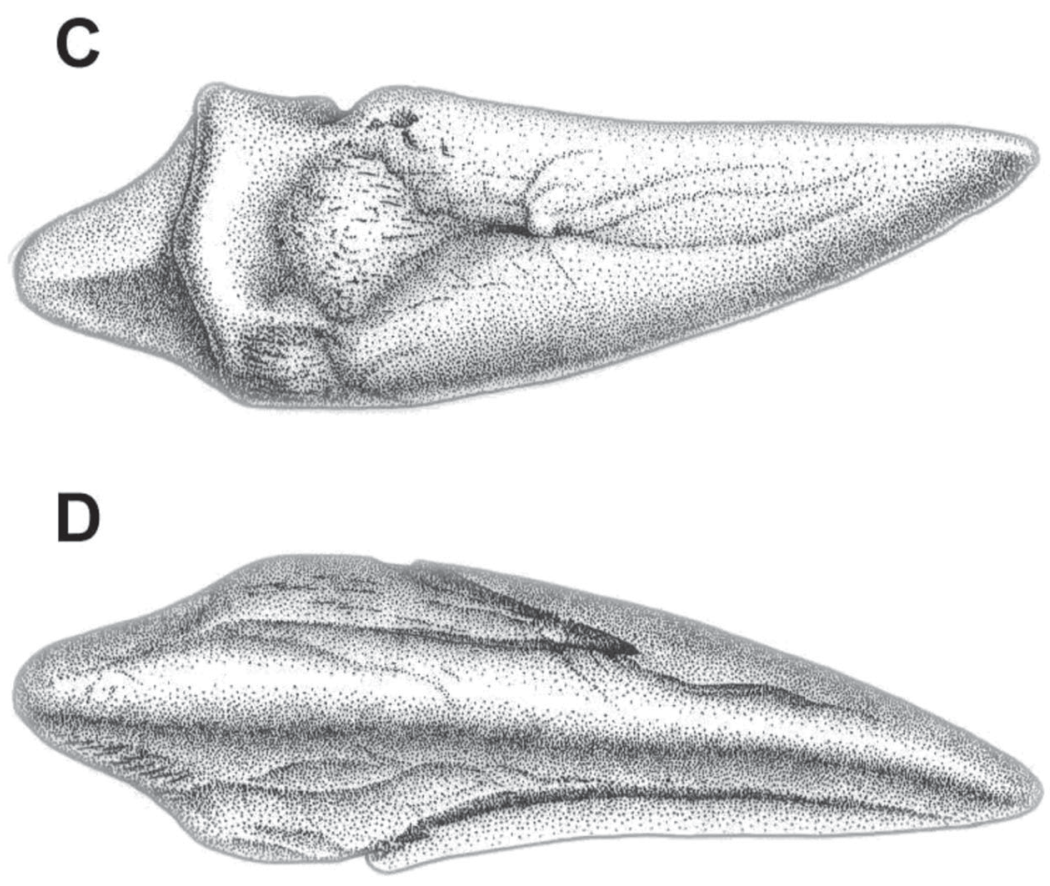

Fig. 1. A-E abelisaurid ungual (MPCM 13573) of digit IV, presumably of the left foot, from the KemKem region. In A, lateral; B, medial; C, ventral; D, dorsal; E, articular views. Scale bar: $2 \mathrm{~cm}$.

longing to Tyrannotitan (Fig. 4) shows sharp distinctions with the "Spinosaurus B" kind of ungual in being strongly curved in side view, subcircular in cross-section, ventrally saddleshaped (i.e., longitudinally concave but transversely convex), and with a relatively pronounced flexor tuberosity. In other words, we dismiss that the elongate, depressed and acuminate pedal unguals of the "Spinosaurus B" kind, belong to Carcharodontosauridae.

We concur with Russell (1996) that cervical vertebrae originally described as "Spinosaurus 

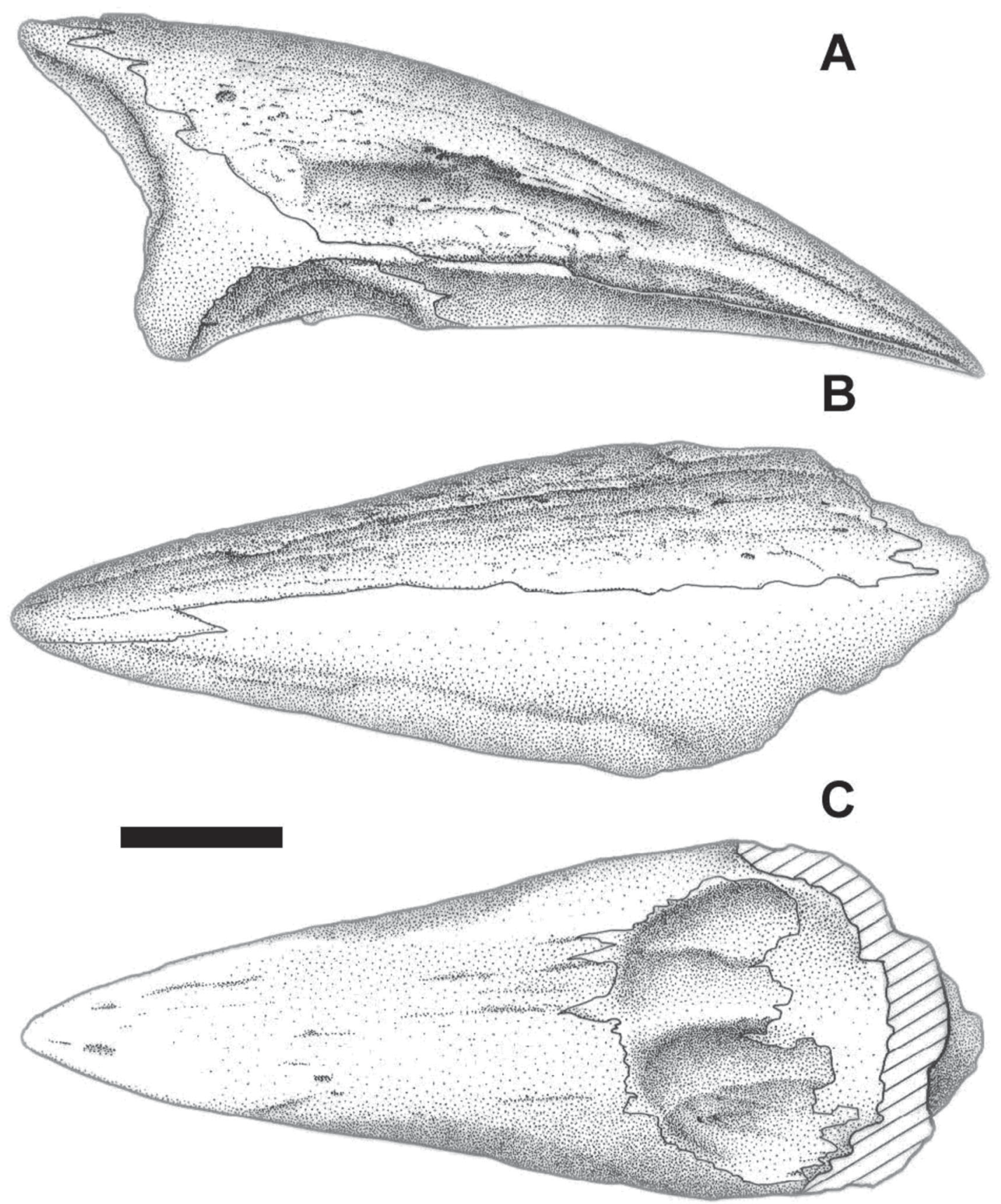

Fig. 2. A-C spinosaurid pedal ungual (MPCM 13574) probably of digit III, from the Kem-Kem region. In, A, lateral (or internal); B, dorsal; C, ventral views. Scale bar: $2 \mathrm{~cm}$.

B" represent a new theropod taxon, Sigilmassasaurus brevicolis. Nevertheless, we interpret that the caudal vertebrae illustrated by both Stromer (1934) and Russell (1996) do not belong to Theropoda, but to Ornithopoda: these caudal centra are closely similar to the ornithischian
Ouranosaurus nigeriensis (Lower Cretaceous of Niger; Taquet, 1976) in the quadrangular-shape of the articular surfaces, as well as the greatly elongated and caudodorsally oriented postzygapophyses. In regards with the appendicular bones referred as "Spinosaurus B" (Stromer, 1934), it is 

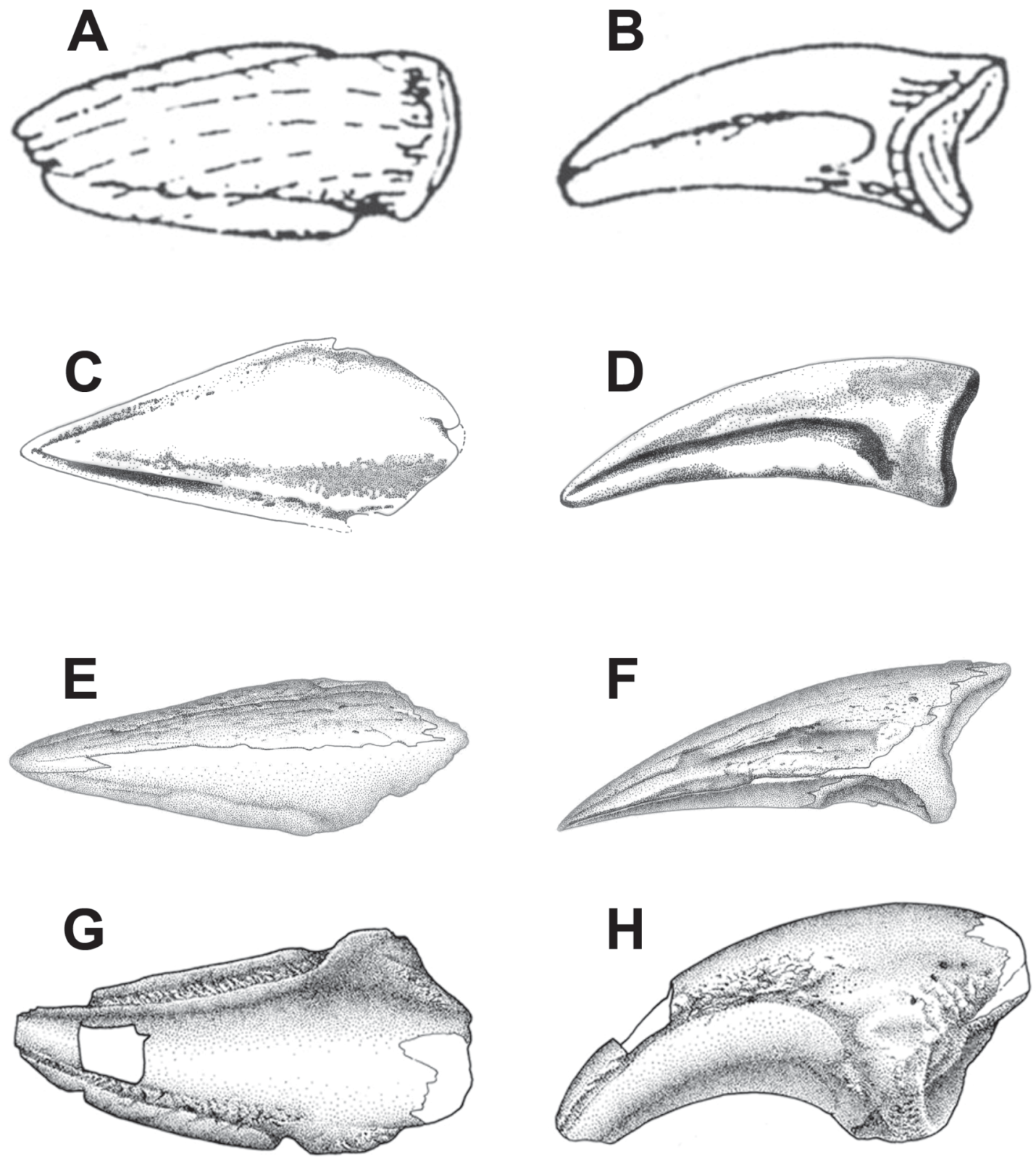

Fig. 3. Pedal unguals of some dinosaur taxa compared. Iguanodon atherfieldensis (from Norman, 1986). "Spinosaurus B" (redrawn from Stromer, 1934). Spinosaurid pedal ungual (MPCM 13574). Tyrannotitan chubutensis (MPEF-PV 1157). A, C, E, G dorsal aspect; B, D, F, H lateral aspect. Not to scale.

improbable that they belong to Spinosauridae because of their elongate and slender construction, and because they show derived characters which are absent in basal tetanurines. Besides, it is almost sure that such slender hind limb bones do to pertain to the bulky Sigilmassasaurus brevicollis. It results obvious that specimen $\mathrm{Nr}$ 1922 x 45 of "Spinosaurus B" consists of a mix- ture of a large but slender theropod (represented by femur and tibia), an iguanodontian ornithopod (represented in the assemblage by the caudal centra), and cervical vertebrae of the ponderous and enigmatic theropod, Sigilmassasaurus (Russell, 1996).

Because of the mixed nature of "Spinosaurus B", it is difficult to discern to which of these taxa 

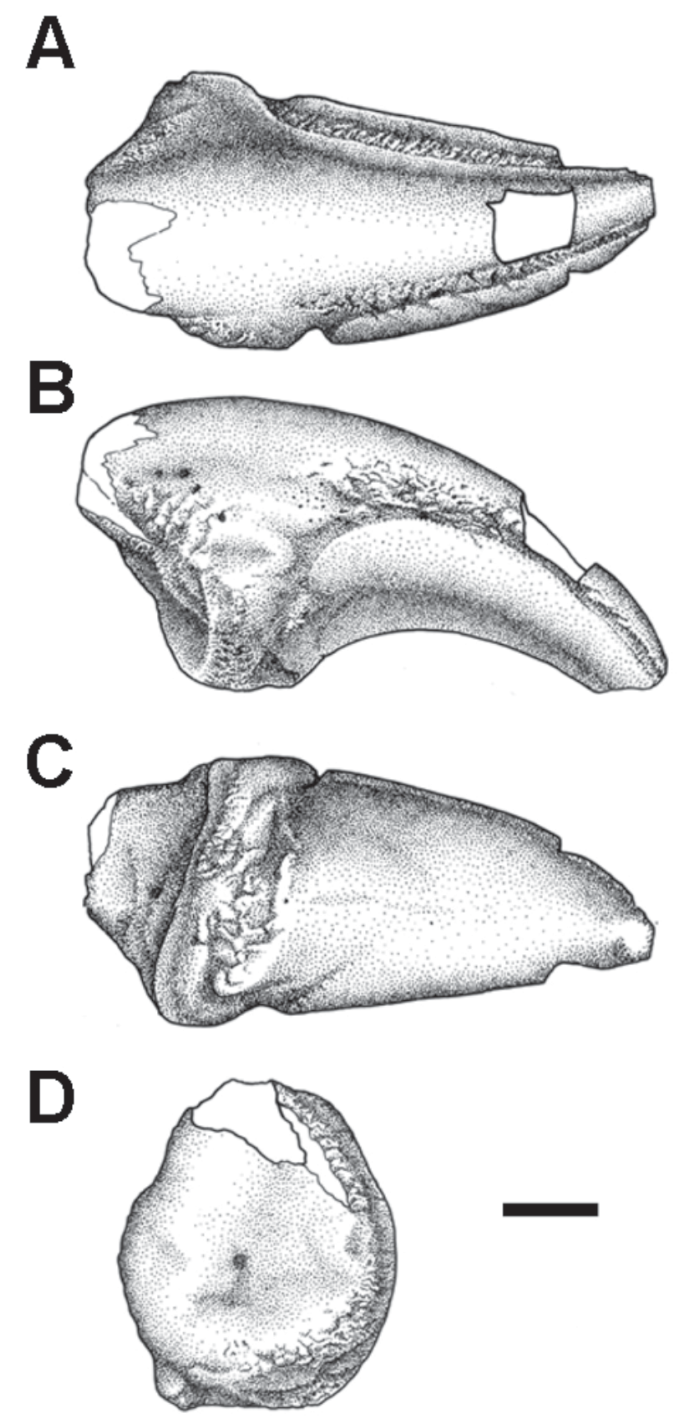

Fig. 4. A-D Tyrannotitan chubutensis (MPEF-PV 1157) pedal ungual of digit II of right foot. In: A, dorsal; $\mathrm{B}$, lateral; $\mathrm{C}$, ventral; and $\mathrm{D}$, articular views. Scale bar: $2 \mathrm{~cm}$.

the pedal ungual under study may belong. Anatomical reasons indicate that the ungual may not correspond to the iguanodontian that produced the caudals: although slightly curved pedal unguals with almost flat ventral surfaces are present in the iguanodontian ornithischian Ouranosaurus (Taquet, 1976), ornithopod pedal unguals (as exemplified by the iguanodontians Talenkauen and Iguanodon; Novas et al., 2004 b; Norman, 1980, 1986) are rounded at their distal tips (excepting for pedal ungual of digit I) and more dorsoventrally flattened, and a proxi-modorsal lip is less well developed. Moreover, ornithopods char- acterize by the presence of well developed, winglike lateroventral ridges, which constitute the ventral bound of the collateral grooves, which are absent in the unguals referred as "Spinosaurus B" (Fig. 3). Finally, unguals of the ornithischian Talenkauen lack the peculiar proximoventral excavation described for "Spinosaurus B".

Besides, giant crocodyles (Stomatosuchus, Sarcosuchus; Stromer, 1925, De Broin, \& Taquet, 1966) are known from Aptian beds from the Sahara, and they may also constitute candidates to produce unguals of this peculiar kind. Unfortunately, unguals of these beasts remain undescribed, and our comparisons become seriously limited to the living Caiman latirrostris. This crocodyle exhibits pedal unguals with ventral surface almost flat, presence of prominent proximodorsal lip, a similar silhouette (e.g., long and slender) in side view, and a distal tip that is acuminate. It is interesting to note that neither crocodyles (i.e., Caiman) nor basal iguanodontians (e.g., Ouranosaurus) exhibit a deep circular depression on the proximal third of ventral surface as seen in the "Spinosaurus B" kind of unguals.

In accordance with previous authors (e.g., Stromer, 1931; Lapparent, 1960), we consider "Spinosaurus B" kind of unguals as belonging to Theropoda, on the basis of the following features: proximodorsal lip prominent, long and slender profile in side view, and distal tip acuminate. However, unguals of the "Spinosaurus B" kind do not fit well with pedal unguals of other theropods. First of all, the low degree of curvature, the almost flat ventral surface of the bone, and the presence of a well excavated proximal flexor fossa on the ventral surface of the bone, represent features not reported yet in the remaining theropods (e.g., abelisauroids, carchardontosaurids, Allosaurus, Tyrannosaurus, Deinonychus). Unfortunately, no information exists about the morphological attributes of spinosaurid pedal unguals, excepting for Baryonyx walkeri (BMNH R 9951; Charig, \& Milner, 1997) a genus that some authors consider as a probable senior synonym of Suchomimus tenerensis and Cristatu-saurus lapparenti (Sues et al., 2002) from the Late Aptian of Niger. Again, the morphology of the only available pedal ungual of Baryonyx fits well with the theropod standard in being dorsoventrally deep, curved in side view, and with prominent flexor tuberosity. Thus, pedal unguals of the basal spinosaurid Baryonyx clearly differ from those of "Spinosaurus B". It is important to note that ungual phalanx of specimen Nr.1922 X 45 may not belong, on the basis of its proportions, to the same animal that produced the slender femur and tibia (here interpreted as a coelurosaurian theropod). 
In sum, we conclude that the "Spinosaurus B" kind of ungual may belong to Theropoda. Considering that the ungual morphology does not match exactly with that known in other theropods, and because the associated cervical vertebrae belong to a bizarre theropod of large size, Sigilmassasaurus brevicollis, we refer with doubts the pedal ungual to this taxon. Available evidence at hand is not clear to elucidate the phylogenetic affinities of this bizarre animal within Theropoda.

\section{DISCUSSION}

Abundant bibliography exists about the MidCretaceous vertebrate taxa shared by Africa and South America (see for example, Bonaparte, 1986; Calvo \& Salgado, 1995; De Broin, 1980; Buffetaut, 1981). Aptian through Cenomanian reptiles recorded on both sides of the Atlantic include theropods of different lineages (e.g., Abelisauroidea, Spinosauridae, Carcharodontosauridae, Dromaeosauridae), as well as a diversity of sauropods (e.g., Rebbachisauridae, Titanosauria), crocodyles (e.g., Sarchosuchus, Araripesuchidae, Notosuchia, and presumably Trematochampsidae), and turtles (e.g., Araripemydae, Pelomedusidae). The common presence of these animals may suggest that a diverse faunal assemblage was uniformly distributed across the southern continents. Nevertheless, little has been investigated about the faunal diversity within Gondwanan continents. In this regard, some distinctions in taxonomic composition become apparent when northern Gondwanan (e.g., African Sahara plus northeastern Brazil) reptile faunas are compared with those recorded at higher latitudes (e.g., Patagonia).

Cenomanian beds of NE Brazil yielded remains of spinosaurid teeth, cervical vertebrae similar to those of Sigilmassaurus, and caudal vertebrae closely resembling those of the iguanodontian Ouranosaurus. Also, remains of large pholidosaurid crocodiles (Bufettaut \& Taquet, 1977) have been found in the Lower Cretaceous of Brazil, suggesting that a fairly uniform faunal assemblage was distributed across Gondwanan lands around to the paleoequator. However, relevant reptile taxa frequently recorded in mid-Cretaceous beds of northern Gondwana (e.g., spinosaurids, sarchosaurids, Sigilmassasaurus-like theropods, Ouranosauruslike iguanodontians), have not been documented so far in the productive Cretaceous outcrops of Patagonia. In contrast with the tran-SaharanBrazilian reptile assemblages, the Patagonian ones were mainly composed by sauropods, seconded by carcharodontosaurid and abelisaurid theropods, with the participation of nonpholodosaurian crocodyles.

Carcharodontosaurids inhabited either low (e.g., Sahara) as well as high paleolatitudes (e.g., Patagonia; Coria \& Salgado, 1995; Novas et al., 2005). Spinosaurids, instead, seem to have preferred regions closer to the Equator. In northern Gondwanan faunas spinosaurids and carcharodontosaurids are abundant while abelisauroids are numerically rare. Reasons to explain such uneven distribution of these theropod clades across Gondwana are difficult to assert. Presumably some kind of latitudinal factor (e.g., temperature, humidity) may have controlled the geographic distribution of the above mentioned reptile taxa.

\section{ACKNOWLEDGEMENTS}

S. Piccini for giving access to the specimens and their casts, A. Milner (BMNH) for allowing access to the Baryonyx walkeri specimen, J. A. González for illustrations, and S. Archangelsky and R. A. Coria for reviewing the manuscript. Finnanced by Agencia Nacional de Promoción Científica y Técnica (Buenos Aires) PICT 13.803 (to F.E.N.).

\section{BIBLIOGRAPHY}

Bonaparte, J. F. 1986. History of the terrestrial Cretaceous vertebrates of Gondwana. IV Congr. Arg. Paleont. Biostrat., 2: 63-95.

- 1991. Los vertebrados fósiles de la Formación Río Colorado, de la ciudad de Neuquén y cercanías, Cretácico Superior, Argentina. Rev. Mus. Arg. Cienc. Nat. "Bernardino Rivadavia". Paleont. 4: 16-123.

Buffetaut, E. 1981. Die biogeographische Geschichte der Krokodilien, mit Beschreibung einer neuen Art, Araripesuchus wegeneri. Geol. Rundsc. 70: 611-624

Buffetaut, E. \& P. Taquet. 1977. The giant crocodilian Sarcosuchus in the Early Cretaceous of Brazil and Niger. Palaeontology 20: 203-208.

Calvo, J. O., \& L. Salgado. 1995. Rebbachisaurus tessonei sp. nov. A new Sauropoda from the AlbianCenomanian of Argentina; new evidence on the origin of the Diplodocidae. Gaia 11: 13-33.

Carrano, M. T., S. D. Sampson \& C. A. Forster. 2002. The osteology of Masiakasaurus knopfleri, a small abelisauroid (dinosauria: theropoda) from the late Cretaceous of Madagascar. J. Vert. Paleont. 22: 510-534.

Coria, R. A. \& L. Salgado. 1995. A new giant carnivorous dinosaur from the Cretaceous of Patagonia. Nature 377: 224-226

Coria, R. A., L. M. Chiappe \& L. Dingus. 2002. A new close relative of Carnotaurus sastrei Bonaparte 1985 (Theropoda: Abelisauridae) from the late Cretaceous of Patagonia. J. Vert. Paleont. 22: 460-465.

Charig, A. J. \& A. C. Milner. 1997. Baryonyx walkeri, a fish-eating dinosaur from the Wealden of Surrey. Bull. Nat. Hist. Mus., Geol. series 53: 11-70.

De Broin, F. 1980. Les tortues de Gadoufaoua (Aptian du Niger) apercu sur la paléobiogéographie des 
Pelomedusida (Pleurodira). Mém. Soc. Géol. France. n.s. 139: 39-46.

De Broin, F. \& P. Taquet. 1966. Découverte d'un crocodilien nouveau dans le Crétacé inférieur du Sahara. C. R. Acad. Sci. Paris, Sci. Nat. 262: 2326-2329.

Deperet C. \& J. Savornin. 1927. La faune de reptiles et de poissons albiens de Timimoun (Sahara Algerien). Bull. Soc. Géol. France, s.4, 27: 257-265.

Huene, F. V. \& C. A. Matley. 1933. The Cretaceous Saurischia and Ornithischia of the central provinces of India. Mem. Geol. Surv. India 21: 1-74.

Jacobs, L. L., D. A. Winkler \& E. M. Gomani. 1996. Cretaceous dinosaurs of Africa: Examples from Cameroon and Malawi. In: F. E. Novas \& R. E. Molnar (eds.): Proceedings of Gondwanan Dinosaur Symposium, Mem. Queens. Mus. 39: 595-610.

Joly, F. 1962. Études sur le relief du sud-est marocain. Travaux de l'Institut des Sciences Chérifien Sér. Géol., Géograp. Phys. 10: 578 pp.

Kellner, A. W. A. \& B. J. Mader. 1996. First report of pterosauria (Pterodactyloidea, Azhdarchidae) from Cretaceous rocks of Morocco. J. Vert. Paleont. 16 (3 suppl.), Abstracts, 45A.

- 1997. Archosaur teeth from the Cretaceous of Morocco. J. Paleont. 71: 525-527.

Lapparent, A. F. de. 1960. Les dinosauriens du "Continental Intercalaire" du Sahara central. Mém. Soc. Géol. France, n. s., 88A: 1-57.

Lavocat, R. 1954. Sur les dinosauriens du continental intercalaire des Kem Kem de la Daoura. Compt. Rend. 19th Int. Geol. Cong., part 15: 65-68.

Mader, B. J. \& A. W. A. Kellner. 1999. A new Anhanguerid pterosaur from the Cretaceous of Morocco. Bol. Mus. Nac. R. Janeiro Geol. 45: 1-11.

Mahler, L. 2005. Record of Abelisauridae (Dinosauria: Theropoda) from the Cenomanian of Morocco. $J$. Vert. Paleont. 25: 236-239

Norman, D. B. 1980. On the ornithischian dinosaur Iguanodon bernissartensis from Belgium. Mém. Inst. Roy. Sci. Nat. Belg. 178: 1-103.

- 1986. On the anatomy of Iguanodon atherfieldensis (Ornithischia: Ornithopoda). Bull. Inst. r. Sci. nat. Belg. Sc. Terre. 56: 281-372

Novas, F. E. \& S. Bandyopadhyay. 2001. Abelisaurid pedal unguals from the Late Cretaceous of India. Asoc. Paleont. Argentina. Public. Esp. 7: 145-149.

Novas, F. E., F. L. Agnolin \& S. Bandyopadhyay. 2004 a. Cretaceous theropods from India: A review of specimens described by Huene \& Matley (1933). Rev. Mus. Argentino Cienc. Nat., 6: 67-103.

Novas, F. E., A. V. Cambiaso \& A. Ambrosio. 2004 b. A new basal iguanodontian (Dinosauria, Ornithischia) from the Upper Cretaceous of Patagonia. Ameghiniana 41: 75-82.

Novas, F. E., S. de Valais, P. Vickers-Rich \& T. Rich. 2005. A large theropod from Patagonia, Argentina, and the evolution of carcharodontosaurids. Naturwissen. 92: 226-230.

Rauhut, O. 1995. Zur systematischen Stellung der afrikanischen Theropoden Carcharodontosaurus Stromer 1931 und Bahariasaurus Stromer 1934. Berliner Geowiss. Abhand., E, 16.1: 357-375.
1999. A dinosaur fauna from the Upper Cretaceous (Cenomanian) of northern Sudan. Palaeont. Africana, 35: 61-84.

Rauhut, O. \& K. Werner. 1995. First record of the family Dromaeosauridae (Dinosauria:Theropoda) in the Cretaceous of Gondwana (Wadi Milk Formation, northern Sudan). Palaeont. Zeits., 69: 475489 .

Russell, D. 1996. Isolated Dinosaur bones from the Middle Cretaceous of the Tafilalt, Morocco. Bull. Mus. Nat. Hist. Nat., Paris, $4^{\circ}$ s. 18: 349-402.

Sereno, P. C., D. B. Dutheil, M. Larochene, H. C. E. Larsson, G. H. Lyon, P. M. Magwene, C. A. Sidor, D. J. Varicchio \& J. A. Wilson. 1996. Predatory dinosaurs from the Sahara and Late Cretaceous faunal differentiation. Science 272: 986-991.

Sereno, P. C., A. L. Beck, D. B. Dutheil, B. Gado, H. C. E. Larsson, G. H. Lyon, J. D. Marcot, O. W. M. Rauhut, R. W. Sadleir, C. A. Sidor, D. D. Varricchio, G. P. Wilson \& J. A. Wilson. 1998. A long-snouted predatory dinosaur from Africa and the evolution of Spinosaurids. Science 282: 1298-1302.

Sereno, P. C., J. A. Wilson \& J. L. Conrad. 2004. New dinosaurs link southern landmasses in the MidCretaceous. Proc. R. Soc. Lond. B 271: 1325-1330.

Stromer, E. 1915. Ergebnisse der Forschungsreisen Prof. E. Stromers in den Wüsten Ägyptens. II Wirbeltier-Reste der Baharîje-Stufe (unterstes Cenoman). 3. Das original des theropoden Spinosaurus aegyptiacus nov. gen. nov. spec. Abhand. Bayer. Akad. Wissen. Math.-phys. Klasse 28. Band, 3. 1-28.

1925. Ergebnisse der Forschungsreise Prof. E. Stromers in den Wüsten Ägyptens. 7. Stomatosuchus inermis Stromer, ein schwach bezahnter Krokodilier. 8. Ein Skelettrest des Pristiden Onchopristis numidus Haug sp. Abh. Bayer. Akad. Wiss. 30: 1-22.

- 1931. Ergebnisse der Forschungsreisen Prof. E. Stromer in den Wüsten Ägyptens. II WirbeltierReste der Baharîjestufe (unterstes Cenoman). 10. Ein Skelett- Rest von Carcharodontosaurus nov.gen. Abhand. Bayer. Akad. Wissen. Math.-phys. Abt. Neue Folge. 9. 1-23.

1934. Ergebnisse der Forschungsreisen Prof. E. Stromers in den Wüsten Ägyptens. II. Wirbeltierreste der Baharîje-Stufe. 13 Dinosauria. Abhand. Bayeris. Akad. Wiss. Math.-naturwiss. Abt. Neue Folge. 22: 1-79.

Sues, H. D., E. Frey, D. M. Martill \& D. M. Scott. 2002. Irritator challengeri, a spinosaurid (dinosaurian: theropoda) from the lower Cretaceous of Brazil. $J$. Vert. Paleont. 22: 535-547.

Taquet, P. 1976. Géologie et Paléontologie du gisement de Gadoufaoua (Aptien du Niger). Cahier Paléont., 1-191, C.N.R.S., Paris.

Taquet, P. \& D. A. Russell. 1998. New data on spino-saurid dinosaurs from the Early Cretaceous of the Sahara. C. R. Acad. Sci., Paris, Sci. Ter. Plan. 327: 347-353.

Wellnhofer, P. \& E. Buffetaut. 1999. Pterosaur remains from the Cretaceous of Morocco. Paläont. Zeits. 73: 133-142. 